\title{
Portland cement clinker production using concentrated solar energy - A proof-of-concept approach
}

\author{
F.A. Costa Oliveira ${ }^{a, *}$, J.C. Fernandes ${ }^{b}$, J. Galindo ${ }^{c}$, J. Rodríguez ${ }^{c}$, I. Cañadas ${ }^{c}$, V. Vermelhudo ${ }^{d}$, \\ A. Nunes ${ }^{\mathrm{d}}$, L.G. Rosa ${ }^{\mathrm{b}}$ \\ ${ }^{a}$ LNEG - Laboratório Nacional de Energia e Geologia I.P., LEN, Laboratório de Energia, UER - Unidade de Energias Renováveis e Integração de Sistemas de Energia, \\ Estrada do Paço do Lumiar, 22, 1649-038 Lisboa, Portugal \\ ${ }^{\mathrm{b}}$ UL - Universidade de Lisboa, IST - Instituto Superior Técnico, DEM - Departamento de Engenharia Mecânica, IDMEC - Instituto de Engenharia Mecânica, Av. Rovisco \\ Pais, 1049-001 Lisboa, Portugal \\ ${ }^{\mathrm{c}}$ PSA - Plataforma Solar de Almería, CIEMAT - Centro de Investigaciones Energéticas, Medioambientales y Tecnológicas, Apartado 22, E-04200 Tabernas (Almería), Spain \\ ${ }^{\mathrm{d}}$ Fábrica Secil-Outão, Apartado 71, 2901-864 Setúbal, Portugal
}

\section{A R T I C L E I N F O}

\section{Keywords:}

Clinker

Solar furnace

Concentrated solar energy

Portland cement

\begin{abstract}
A B S T R A C T
The aim of this work was to demonstrate the feasibility of producing Portland cement clinker upon direct exposure of the raw materials under concentrated solar radiation using the PSA high concentration solar furnace SF40. For this purpose, a short thermal cycle $(<40 \mathrm{~min})$ was devised including 5 min dwell times at temperatures in the range $900-950^{\circ} \mathrm{C}$ and $1250-1300{ }^{\circ} \mathrm{C}$, followed by $10-15 \mathrm{~min}$ at $1500-1550{ }^{\circ} \mathrm{C}$. The chemical and mineralogical data of the grey clinker produced are encouraging since values of $51.0 \pm 6.9 \% \mathrm{C}_{3} \mathrm{~S}, 22.7 \pm 5.3 \%$ $\mathrm{C}_{2} \mathrm{~S}, 8.6 \pm 0.4 \% \mathrm{C}_{3} \mathrm{~A}$ and $10.8 \pm 0.7 \% \mathrm{C}_{4} \mathrm{AF}$ are similar to those observed for conventional clinker used for the production of Portland cement in accordance to EN 197-1 standard. White clinker, in turn, could not be produced by direct irradiation in this setup conditions because of its low absorptance of solar energy.
\end{abstract}

\section{Introduction}

It is of no surprise that concrete produced from Portland cement is one of the most versatile construction materials used in the world. The global production of Portland cement was estimated to be roughly 4.1 Gt in 2017 (van Oss, 2018).

The European Standard EN 197-1 defines Portland cement clinker as a hydraulic material consisting of at least two-thirds by mass of calcium silicates, the remainder being $\mathrm{Al}$ - and Fe-containing phases and other compounds.

Portland cement clinker is typically made by heating, in a rotary kiln, a homogenous mixture of calcaneus (i.e. containing $\mathrm{CaCO}_{3}$ or other insoluble calcium salts) and argillaceous (i.e. clay-like) materials to a calcining temperature above $600{ }^{\circ} \mathrm{C}$ and then fired, normally at temperatures around $1500^{\circ} \mathrm{C}$, to produce a fine powder known as clinker (Sorrentino, 2011). When clinker is mixed with typically $6 \%$ gypsum $\left(\mathrm{CaSO}_{4} \cdot 2 \mathrm{H}_{2} \mathrm{O}\right)$, one gets Portland cement (Moir, 1997, ASTM C 150-07, 2007).

Breaking the reaction processes into a number of simple zones, one can make some approximations about the clinker formation process, in a rotatory kiln, where the following main reactions take place (Baron and Ollivier, 1996):

Zone 1: $2 \mathrm{~min}, 800-900{ }^{\circ} \mathrm{C}$

Decomposition of calcium carbonate as follows:

heat

$\mathrm{CaCO}_{3} \rightarrow \mathrm{CaO}+\mathrm{CO}_{2}$

Zone 2: $15 \mathrm{~min}, 900-1300{ }^{\circ} \mathrm{C}$

Formation of secondary silicate phases, mainly $2 \mathrm{CaO} \cdot \mathrm{SiO}_{2}$ (up to $1200^{\circ} \mathrm{C}$ ) as follows:

$2 \mathrm{CaO}+\mathrm{SiO}_{2} \rightarrow 2 \mathrm{CaO} \cdot \mathrm{SiO}_{2}$

Zone 3: $12 \mathrm{~min}, 1300-1450{ }^{\circ} \mathrm{C}$

Sintering and reaction within the melt to form ternary silicates and tetracalcium aluminoferrates:

$$
\begin{gathered}
\text { heat }+ \text { time } \\
2 \mathrm{CaO} \cdot \mathrm{SiO}_{2}+\mathrm{CaO} \rightarrow 3 \mathrm{CaO} \cdot \mathrm{SiO}_{2} \\
\text { heat }+ \text { time } \\
3 \mathrm{CaO} \cdot \mathrm{Al}_{2} \mathrm{O}_{3}+\mathrm{CaO}+\mathrm{Fe}_{2} \mathrm{O}_{3} \rightarrow 4 \mathrm{CaO} \cdot \mathrm{Al}_{2} \mathrm{O}_{3} \cdot \mathrm{Fe}_{2} \mathrm{O}_{3}
\end{gathered}
$$

\footnotetext{
* Corresponding author at: Estrada do Paço do Lumiar, 22, 1649-038 Lisboa, Portugal.

E-mail address: fernando.oliveira@lneg.pt (F.A.C. Oliveira).
} 